\title{
Irrigation and Fertilizer Management in Cowpea under Zero Tilled Condition of South Konkan Coastal Zone of Maharashtra, India
}

\author{
V.A. Rajemahadik*, V.N. Shetye, V.G. Chavan, S.A. Chavan and U.V. Mahadkar \\ ${ }^{1}$ Department of Agronomy, College of Agriculture, Dapoli, DBSKKV, Dapoli, \\ Maharashtra, India \\ *Corresponding author
}

\begin{tabular}{|c|}
\hline Keywords \\
\hline $\begin{array}{l}\text { Cowpea, Zero } \\
\text { tillage, Fertilizer }\end{array}$ \\
\hline Article Info \\
\hline $\begin{array}{l}\text { Accepted: } \\
\text { 20 November } 2018 \\
\text { Available Online: } \\
10 \text { December } 2018\end{array}$ \\
\hline
\end{tabular}

\section{A B S T R A C T}

\begin{abstract}
A field experiment was conducted for three consecutive years commencing from 2011-12 to 2013-14 at Agronomy farm, College of Agriculture, Dapoli Dist. Ratnagiri, Maharashtra, India to study the Effect of irrigation and levels of fertilizer application on zero tilled cowpea (Vigna unguiculata L.). The experiment was laid out in a split plot design with three replications. The main plot treatments were three irrigation levels, viz., no irrigation $\left(\mathrm{I}_{0}\right)$, one irrigation at branching $\left(\mathrm{I}_{1}\right)$ and two irrigations at branching and pod filling stage $\left(\mathrm{I}_{2}\right)$. The sub plot treatments comprised six fertilizer levels viz., no fertilizer $\left(\mathrm{F}_{0}\right), 25 \%$ RDF below seed placement $\left(\mathrm{F}_{1}\right), 50 \%$ RDF below seed placement $\left(\mathrm{F}_{2}\right), 75 \%$ RDF below seed placement $\left(\mathrm{F}_{3}\right), 100 \%$ RDF below seed placement $\left(\mathrm{F}_{4}\right)$ and $100 \%$ RDF through line application $\left(\mathrm{F}_{5}\right)$. Thus, there were in all 18 treatment combinations. The gross plot size was $4.2 \mathrm{~m} \times 3.3 \mathrm{~m}$ and net plot size was $3.6 \mathrm{~m} \times 3 \mathrm{~m}$, respectively. The soil of the experimental plot was uniform, leveled and well drained. It was sandy clay loam in texture, medium in available nitrogen $\left(298.20 \mathrm{~kg} \mathrm{ha}^{-1}\right)$, low in available phosphorus (11.80 $\left.\mathrm{kg} \mathrm{ha}^{-1}\right)$, moderately high in available potassium $\left(249.35 \mathrm{~kg} \mathrm{ha}^{-1}\right)$, medium in organic carbon $(0.95 \%)$ and slightly acidic in reaction ( $\mathrm{pH} 5.8)$. Results revealed that application of two irrigations (at branching and pod filling stage) recorded significantly higher growth as well as yield attributes resulting in higher grain and stover yield followed by treatment in which one irrigation (at branching) and control treatment. Application of 100\% RDF below seed placement recorded significantly higher growth as well as yield attributes resulting in higher grain and stover yield followed by 100\% RDF through line application and $75 \%$ RDF below seed placement over rest of the treatments. In respect of economics, it was observed that the treatment combinations $\mathrm{I}_{2} \mathrm{~F}_{4}$ (two irrigations at branching and pod filling stage $+100 \%$ RDF below seed placement) has given highest net returns and $\mathrm{B}: \mathrm{C}$ ratio.
\end{abstract}

\section{Introduction}

Cowpea is a broadly adapted and highly variable crop, cultivated around the world primarily as a pulse, but also as a vegetable (both for the greens and the green peas), a cover crop, and for fodder. Pulses are considered to be an important group of crops in conserving natural resources such as soil, water and nutrients. Water requirement of 
pulses are lower than cereals. Global water consumption of cereals is reported to be about $60 \%$ as against $4 \%$ in pulses.

Cowpea commonly known as "Lobia" is used as pulse, a fodder and green manure crop. It is considered as miracle crop of the world. It is an important multipurpose arid grain legume extensively used in arid and semi-arid regions.

The reason for the low yield of the pulse crop may be many but the important one is that the pulse crop hardly receives any irrigation and fertilizer. The question of water and fertilizer use efficiency assumes much greater importance in the context of the need to increase food grain production substantially to meet the demand of ever increasing population. The diverse climatic and soil conditions prevailing in India make it possible to grow a wide variety of crops. It also results in a variety of fertilizer management problems. Therefore, it is essential to improve water as well as fertilizer use efficiency. The efficient utilization of these two key inputs would not only enhance food production but also reduce the cost of food production.

Water management in cowpea is an important aspect of increasing the production. The review on water management of kharif and rabi pulses has clearly indicated that the water management depends largely on agro-climatic conditions of the locality. On the basis of recent scientific evidences, there is urgent necessity to work out the water need of the pulses crop from evaporative demand of the tract. Importance of irrigation at critical growth stages should be recognized. Available moisture in soil should be conserved by adopting moisture conserving techniques.

Zero tillage or no tillage is a farming system in which the seeds are directly deposited into untilled soil which has retained the previous crop residues. It is also referred to as no-till.
Zero tillage is cultivation practice that not only helps to preserve soil fertility and conserves scarce water, but boosts yield and increases farmer's profits by reducing their production costs. Zero tillage is a system of planting (seeding) crops into untilled soil by opening a narrow slot or trench only of sufficient width and depth to obtain proper seed coverage. No other soil tillage is done. Due to zero tillage the costs reduced about 15 to 16 per cent. Zero tillage having positive environmental impacts in the Indo-Gangatic plains. It saves fossil fuels and reduces greenhouse gas emissions, and cuts water use.

In konkan region of Maharashtra, pulses are mainly grown in rabi season in rice field after harvest of rice crop both on residual moisture as well as under irrigation. The cultivation of cowpea in rice fallows is reported to be more profitable than horse gram and mustard. The average productivity of pulses in konkan is found to be very low. Among various pulses, which are liked and relished by konkan people is cowpea. The reasons for the low yield of cowpea grown on residual moisture in zero tilled condition are that cowpea hardly receives any irrigation at critical growth stages during hot weather. Another cause for low yield of cowpea is lack of suitable method and level of fertilizer application to crop grown on residual moisture. Therefore, to exploit high yielding potential of cowpea on residual moisture, better management of these aspects needs to be emphasis.

\section{Materials and Methods}

A field experiment was conducted at the Agronomy Farm, College of Agriculture, Dr. Babasaheb Sawant Konkan Krishi Vidyapeeth, Dapoli, Dist. Ratnagiri (M.S.) during rabi season of 2011 to 2013. Farm is situated at 17${ }^{0} .45^{\prime} \mathrm{N}$ latitude and $73^{0} .1$ ' E longitude having altitude of 250 meters above the mean sea level. As experiment is based on zero tillage 
technology, immediately after harvesting of kharif rice without doing any tillage operation rabi cowpea was sown. The selection of site was considered on the basis of suitability of land for cultivation of cowpea. Climatologically, this area falls in the subtropical region with mean annual precipitation of $3500 \mathrm{~mm}$, which is generally received from June to October in about 95 to 100 days.

Soil of the experimental plot was classified as lateritic, derived from mixed parent material. Mineralogically these soils have kaolinite as a predominant clay mineral associated with some quantity of illite. The experimental field has a flat topography with ideal conditions for cowpea cultivation during rabi season. Composite soil samples were collected from $0.30 \mathrm{~cm}$ depth before the layout of experiment with the help of screw auger for studying physical and chemical properties of soil. The soil of experimental plot was sandy clay loam in texture and slightly acidic in reaction with medium in organic carbon content (0.95). It was medium in available nitrogen $(298.20 \mathrm{Kg}$ $\left.\mathrm{ha}^{-1}\right)$ and low in available phosphorus (11.80 $\mathrm{Kg} \mathrm{ha}{ }^{-1}$ ) and moderately high in available potassium (249.35 $\mathrm{kg} \mathrm{ha}^{-1}$ ) with $\mathrm{pH}$ 5.8.The experiment was laid out in split plot design with three replications. The experiment was laid out in a split plot design with three replications. The main plot treatments were three irrigation levels, viz., no irrigation $\left(\mathrm{I}_{0}\right)$, one irrigation at branching $\left(\mathrm{I}_{1}\right)$ and two irrigations at branching and pod filling stage $\left(\mathrm{I}_{2}\right)$. The sub plot treatments comprised six fertilizer levels viz., no fertilizer $\left(\mathrm{F}_{0}\right), 25 \%$ RDF below seed placement $\left(\mathrm{F}_{1}\right), 50 \% \mathrm{RDF}$ below seed placement $\left(\mathrm{F}_{2}\right), 75 \%$ RDF below seed placement $\left(\mathrm{F}_{3}\right), 100 \%$ RDF below seed placement $\left(\mathrm{F}_{4}\right)$ and $100 \%$ RDF through line application $\left(\mathrm{F}_{5}\right)$. Thus, there were in all 18 treatment combinations. The gross plot size was $4.2 \mathrm{~m}$ x $3.3 \mathrm{~m}$ and net plot size was $3.6 \mathrm{~m}$ x $3 \mathrm{~m}$, respectively. The pure seed of variety
Konkan Sadabahar was obtained from Department of Agronomy, Dapoli. Bold and well-developed seeds were selected as for sowing. Cowpea genotype Konkan Sadabahar released by Dr. Balasaheb Sawant Konkan Krishi Vidyapeeth, Dapoli, Ratnagiri (M.S.). It is most suited for post rainy (rabi) and also summer season. It takes 65 to 75 days for maturity, gives high pod, seed yields.

The quantity of fertilizer dose for each plot was calculated as per the treatments. RDF was applied at 4 different levels viz., 25\%, 50\%, $75 \%$ and $100 \%$ each through urea $(46.4 \% \mathrm{~N})$ and single super phosphate $\left(16 \% \mathrm{P}_{2} \mathrm{O}_{5}\right)$. The whole quantity of urea and single super phosphate was applied in a single below seed placement before sowing of seeds for treatments $F_{1}$ to $F_{4}$. The fertilizers for $F_{5}$ plots were applied through line application after germination of crop. The seeds used for sowing were treated with the fungicide thirum (a) $3 \mathrm{~g} \mathrm{~kg}^{-1}$ seed prior to culture treatments. A common Rhizobium seed treatment @ $250 \mathrm{~g}$ $10 \mathrm{~kg}^{-1}$ of seed was given to the fungicide treated seeds before sowing.

Under zero tillage condition, the fertilizers were applied uniformly to the whole plot in the holes dibbled earlier at the spacing of $30 \mathrm{x}$ $15 \mathrm{~cm}$. The whole quantity of nitrogen and phosphorous (25:50 kg NP ha ${ }^{-1}$ ) were applied as a basal dose. Whole quantity of fertilizers was uniformly mixed and it was applied 3-4 $\mathrm{cm}$ below the seed to avoid the direct contact of seed with fertilizers. The calculated quantity of $\mathrm{N}$ and $\mathrm{P}_{2} \mathrm{O}_{5}$ was applied through urea and single super phosphate, respectively.

After fertilizer application the seeds were sown in the holes dibbled. Two to three seeds were dibbled at each spot at about $5 \mathrm{~cm}$ depth. Care was taken to avoid direct contact of seed with fertilizer. Seeds were properly covered with the soil to avoid the damage from birds. Care was also taken to protect the germinating 
seeds from bird damage. Gap filling was done 8 to 10 days after sowing and thinning was done at 12-15 days after sowing.

In the present investigation, two irrigations were applied as per treatments at branching and pod filling stage to the respective plots, for that purpose irrigations were given to respective treatment plots by flexi pipe, as small bunds were raised around each respective plot. Immediately, after harvesting of kharif rice existing weeds were controlled by applying non-selective herbicide Glyphosate @ $2 \mathrm{~kg}$ a.i. / ha. Plant protection measures against various pests were undertaken by spraying endosulphan, cypermethrin and phosphamidon @ $0.1, \quad 0.1$ and $0.03 \%$ respectively for plant hoppers, aphids and pod borer during period of experimentation.

The experimental crop was harvested when the pods matured fully. Harvesting was carried out manually by picking the pods. Three pickings were done. Five observation plants were harvested separately for recording the post-harvest observations. The pods from each plot were also sun dried for 8-10 days and then their weights were recorded after complete drying. The plot wise threshing and cleaning operations were carried out. Subsequently, the grain yield was recorded and straw yield was computed by weighing the dried straw without pods. Number of branches per plant was studied by counting the main and lateral branches collectively of five randomly selected plants from each net plot and the average number of branches per plant was worked out. For dry matter, two plants were randomly selected from each net plot at the time of every periodical observation.

After harvesting the mature pods obtained from each net plot was dried in the sun till constant weight was obtained and then it was recorded as dry pod yield per net plot. In this weight, weight of dry pods from five observation plants is added. This was further converted on hectare basis. The plot wise grain yield data was recorded after proper drying, threshing and cleaning of cowpea grains. The plot wise data was then converted on hectare basis (t/ha).The straw obtained from each treatment plot was sundried for about 10 days, weighed and then per plot straw yield data was recorded and converted on hectare basis (t/ha).

Measurement of soil moisture content was made periodically by gravimetric method. Soil samples were collected in aluminium moisture boxes with help of screw auger from the depth of 0-15 and $15-30 \mathrm{~cm}$ at 15 days interval and also before and after irrigation during life cycle of crop. The soil moisture content was determined by oven drying the soil samples at $105^{0} \mathrm{C}$ for 8 hours and expressed as percentage of oven dry soil as given below.

The treatment wise representative surface soil samples (up to $22.5 \mathrm{~cm}$ ) were collected both at initial and at harvest with the help of screw auger. These samples were air dried in shade, pounded in wooden mortar and pestle, for chemical analysis. The statistical analysis of data of characters studied during the course of investigation was carried out through the procedure appropriate to the design of the experiment as described by Panse and Sukhatme (1967).

The net income was obtained by deducting the total cost of cultivation from the gross returns. The benefit: cost ratio (B: C) was calculated by dividing the gross income by the total cost of cultivation of each treatment.

\section{Results and Discussion}

\section{Growth parameters}

The growth characters at harvest viz., plant height and dry matter per plant were significantly affected by irrigation levels 
during year 2011-12, 2012-13 and 2013-14. Treatment $\mathrm{I}_{2}$ (Two irrigation at branching and pod filling stage) recorded significantly more plant height and dry matter per plant over rest of the irrigation levels except for dry matter production where one irrigation at branching $\left(\mathrm{I}_{1}\right)$ remained at par with treatment $\mathrm{I}_{2}$ during year2012-13.The treatment $\mathrm{F}_{4}(100 \%$ R.D.F. below seed placement) recoded significantly more plant height and dry matter per plant over all other fertilizers levels, except treatment $\mathrm{F}_{5}$ which were at par with each other during year 2011-12, 2012-13 and 2013-14.

The increase in plant height was mainly attributed due to availability of irrigations at these two critical growth stages of cowpea. Two irrigations at critical stages of the crop resulted in very good cell turgidity there by increasing the cell elongation resulting in taller plants. Similar increase in growth characters under application of irrigation at branching stage and pod development stage was in close agreement with Shersingh et al., (2004) (Table 1).

Increase in dry matter production per unit area is a first step towards achieving higher yield. The decrease in grain yield is proportional to the decrease in accumulated biomass. Dry matter production is an important pre-requisite for higher yields as it signifies photosynthetic ability of the crop and also indicates other synthetic process during developmental sequences.

The increased dry matter per plant may be attributed to the significant increase in morphological and physiological parameters which are responsible for the photosynthetic capacity of the plant thereby increasing the biological yield. Further, application of irrigation at branching and pod filling stage produce higher dry matter. This may be owing to availability of sufficient moisture during vegetative and reproductive stages. These results are in same line with the findings Bachchhav et al., (1994), Shersingh et al., (2004).

After supplying ample amount of $\mathrm{N}, \mathrm{P}_{2} \mathrm{O}_{5}$ and $\mathrm{K}_{2} \mathrm{O}$ as in case of $\mathrm{F}_{4}$ and $\mathrm{F}_{5}$ contributed probably higher chlorophyll content which enables the crops photosynthetically more active and therefore higher dry matter accumulation which has reflected in recording of superior values of growth parameters. After supplying ample amount of $\mathrm{N}, \mathrm{P}_{2} \mathrm{O}_{5}$ andK ${ }_{2} \mathrm{O}$ as in case of $\mathrm{F}_{4}$ and $\mathrm{F}_{5}$ contributed probably higher chlorophyll content which enables the crops photosynthetically more active and therefore higher dry matter accumulation which has reflected in recording of superior values of growth parameters such as plant height $(\mathrm{cm})$, dry matter accumulation (g) followed by treatments $F_{3}, F_{2}, F_{1}$ and $F_{0}$.

Our findings are in close agreement with those reported by Rana and Singh (1998), Singh et al., (2006).

\section{Yield attributes}

The main objective of the agronomist is to increase the economic yield which is grain in case of cowpea. The grain yield per unit area in cowpea is a function of yield attributes of an individual plant viz., number of pods per plant, number of grains per pod, grain weight per plant and 100 seed weight were significantly influenced by irrigation levels during year 2011-12, 2012-13 and 2013-14. Treatment $\mathrm{I}_{2}$ (Two irrigation at branching and pod filling stage) recorded significantly more number of pods per plant, number of grains per pod, grain weight per plant and 100 seed weight over rest of the treatment during year 2011-12, 2012-13 and 2013-14.Treatment $F_{4}$ (100 \% R.D.F. placement below seed) recorded significantly higher number of pods per plant, number of grains per pod, grain weight per plant and 100 seed weight over all 
other treatment, except treatment $\mathrm{F}_{5}$ for 100 seed weight, which remained at par with each other during year 2011-12, 2012-13 and 201314. The results revealed that, application of two irrigations at branching and pod filling stages significantly improved all the yield attributing characters followed by one irrigation at branching and control. The possible reason of high yield attributing characters may be traced due to the increased dry matter production might have resulted in greater synthesis of photosynthates contributing to an increase in yield attributes.
The beneficial effect of application of irrigation resulted in improved yield attributes was also be noticed by Sawant et al., (1992), Shersingh et al., (2004), Hossain et al., (2009).The plant nutrients are most important for growth and development of crops. When soil content less available nutrients, plant cannot absorb sufficient amount of nutrients from soil ultimately, it results in to reduction in yield of crop. Availability of optimum amount of essential plant nutrients resulted in a production of superior yield attributes (Table 2 and 3$)$.

Table.1 Growth characters of cowpea as influenced by different treatments during year 2011-12, 2012-13 and 2013-14

\begin{tabular}{|c|c|c|c|c|c|c|}
\hline \multirow[t]{2}{*}{ Treatments } & \multicolumn{3}{|c|}{ Height (cm) } & \multicolumn{3}{|c|}{ Dry matter/plant (g) } \\
\hline & 2011-12 & 2012-13 & 2013-14 & 2011-12 & 2012-13 & 2013-14 \\
\hline \multicolumn{7}{|l|}{ Irrigation levels } \\
\hline $\mathbf{I}_{0}$ : Control & 14.05 & 14.11 & 12.87 & 3.56 & 3.82 & 3.63 \\
\hline $\mathbf{I}_{1}$ : One irrigation (At Br.) & 15.83 & 14.72 & 13.76 & 6.28 & 4.62 & 4.04 \\
\hline $\begin{array}{l}\mathbf{I}_{2} \text { : Two irrigation (At Br. } \\
\text { and P.F.) }\end{array}$ & 17.50 & 15.75 & 14.43 & 7.26 & 4.97 & 4.65 \\
\hline F. test & Sig. & Sig. & Sig. & Sig. & Sig. & Sig. \\
\hline S.Em. \pm & 0.38 & 0.09 & 0.13 & 0.23 & 0.11 & 0.11 \\
\hline C.D. at $5 \%$ & 1.49 & 0.35 & 0.51 & 0.89 & 0.43 & 0.41 \\
\hline \multicolumn{7}{|l|}{ Fertilizer levels } \\
\hline $\mathbf{F}_{\mathbf{0}}:$ Control & 12.69 & 13.40 & 12.49 & 3.54 & 3.01 & 2.93 \\
\hline $\begin{array}{l}\mathbf{F}_{1}: 25 \% \text { RDF below seed } \\
\text { placement. }\end{array}$ & 13.84 & 14.17 & 13.13 & 4.39 & 3.60 & 3.33 \\
\hline $\begin{array}{l}\mathbf{F}_{2}: 50 \% \text { RDF below seed } \\
\text { placement. }\end{array}$ & 14.98 & 14.87 & 13.51 & 5.27 & 4.68 & 3.90 \\
\hline $\begin{array}{l}\text { F }_{3}: 75 \% \text { RDF below seed } \\
\text { placement. }\end{array}$ & 16.82 & 15.34 & 14.00 & 6.11 & 5.02 & 4.40 \\
\hline $\begin{array}{l}\mathbf{F}_{4}: 100 \% \text { RDF below seed } \\
\text { placement. }\end{array}$ & 18.63 & 15.74 & 14.65 & 7.72 & 5.34 & 5.14 \\
\hline $\begin{array}{l}\mathbf{F}_{5}: 100 \% \text { RDF through } \\
\text { line application }\end{array}$ & 17.78 & 15.64 & 14.33 & 7.14 & 5.14 & 4.93 \\
\hline F. test & Sig. & Sig. & Sig & Sig. & Sig. & Sig. \\
\hline S.Em. \pm & 0.31 & 0.11 & 0.09 & 0.28 & 0.07 & 0.110 \\
\hline C.D. at $5 \%$ & 0.89 & 0.32 & 0.27 & 0.81 & 0.22 & 0.319 \\
\hline General mean & 15.79 & 14.86 & 13.69 & 5.70 & 4.47 & 4.11 \\
\hline
\end{tabular}


Table. 2 Yield attributing characters of cowpea as influenced by different treatments during year 2011-12, 2012-13 and 2013-14

\begin{tabular}{|c|c|c|c|c|c|c|}
\hline \multirow[t]{3}{*}{ Treatments } & \multicolumn{3}{|c|}{ Number of pods plant ${ }^{-1}$} & \multicolumn{3}{|c|}{ Number of grains pod ${ }^{-1}$} \\
\hline & \multirow[t]{2}{*}{ 2011-12 } & \multirow[t]{2}{*}{ 2012-13 } & \multirow[t]{2}{*}{ 2013-14 } & & & \\
\hline & & & & 2011-12 & 2012-13 & 2013-14 \\
\hline \multicolumn{7}{|l|}{ Irrigation levels } \\
\hline $\mathrm{I}_{0}:$ Control & 7.48 & 9.48 & 9.62 & 8.19 & 7.88 & 6.98 \\
\hline $\begin{array}{l}\mathrm{I}_{1}: \text { One irrigation (At } \\
\text { Br.) }\end{array}$ & 8.98 & 10.87 & 10.58 & 9.87 & 8.08 & 7.14 \\
\hline $\begin{array}{l}\mathrm{I}_{2}: \text { Two irrigation (At } \\
\text { Br. and P.F.) }\end{array}$ & 11.28 & 11.61 & 11.53 & 10.78 & 8.65 & 7.15 \\
\hline F. test & Sig. & Sig. & Sig & Sig. & Sig. & Sig. \\
\hline S.Em. \pm & 0.19 & 0.13 & 0.14 & 0.17 & 0.07 & 0.073 \\
\hline C.D. at $5 \%$ & 0.77 & 0.53 & 0.56 & 0.65 & 0.28 & 0.286 \\
\hline \multicolumn{7}{|l|}{ Fertilizer levels } \\
\hline $\mathrm{F}_{0}:$ Control & 6.93 & 6.13 & 6.31 & 8.29 & 6.68 & 6.21 \\
\hline $\begin{array}{l}\mathrm{F}_{1}: 25 \% \text { RDF below } \\
\text { seed placement }\end{array}$ & 7.89 & 8.89 & 8.73 & 8.82 & 7.47 & 7.15 \\
\hline $\begin{array}{l}\mathrm{F}_{2}: 50 \% \text { RDF below } \\
\text { seed placement }\end{array}$ & 8.93 & 11.13 & 10.96 & 9.40 & 8.45 & 7.04 \\
\hline $\begin{array}{l}\mathrm{F}_{3}: 75 \% \text { RDF below } \\
\text { seed placement }\end{array}$ & 9.82 & 12.00 & 12.00 & 10.02 & 8.57 & 7.18 \\
\hline $\begin{array}{l}\mathrm{F}_{4}: 100 \% \text { RDF below } \\
\text { seed placement }\end{array}$ & 11.42 & 13.27 & 13.02 & 10.91 & 9.36 & 7.53 \\
\hline $\begin{array}{l}\mathrm{F}_{5}: 100 \% \mathrm{RDF} \text { through } \\
\text { line application }\end{array}$ & 10.47 & 12.49 & 12.44 & 10.23 & 8.67 & 7.44 \\
\hline F. test & Sig. & Sig. & Sig & Sig. & Sig. & Sig \\
\hline S.Em. \pm & 0.299 & 0.21 & 0.152 & 0.19 & 0.16 & 0.09 \\
\hline C.D. at $5 \%$ & 0.863 & 0.60 & 0.440 & 0.55 & 0.46 & 0.26 \\
\hline General mean & 9.24 & 10.65 & 10.58 & 9.61 & 8.20 & 7.09 \\
\hline
\end{tabular}


Table.3 Yield attributing characters of cowpea as influenced by different treatments during year 2011-12, 2012-13 and 2013-14

\begin{tabular}{|c|c|c|c|c|c|c|}
\hline \multirow[t]{2}{*}{ Treatments } & \multicolumn{3}{|c|}{ Grain weight plant ${ }^{-1}(\mathrm{~g})$} & \multicolumn{3}{|c|}{100 seed weight $(\mathrm{g})$} \\
\hline & $\begin{array}{c}2011- \\
12\end{array}$ & $\begin{array}{c}2012- \\
13\end{array}$ & 2013-14 & 2011-12 & 2012-13 & 2013-14 \\
\hline \multicolumn{7}{|l|}{ Irrigation levels } \\
\hline $\mathrm{I}_{0}$ : Control & 5.05 & 5.95 & 5.73 & 8.34 & 8.21 & 8.00 \\
\hline $\mathrm{I}_{1}:$ One irrigation (At Br.) & 6.14 & 6.19 & 6.42 & 8.41 & 8.30 & 8.22 \\
\hline $\begin{array}{l}\mathrm{I}_{2}: \text { Two irrigation (At Br. } \\
\text { and P.F.) }\end{array}$ & 7.17 & 6.57 & 6.72 & 8.51 & 8.38 & 8.29 \\
\hline F. test & Sig. & Sig. & Sig & Sig. & Sig. & Sig \\
\hline S.Em. \pm & 0.11 & 0.05 & 0.02 & 0.02 & 0.02 & 0.039 \\
\hline C.D. at $5 \%$ & 0.44 & 0.20 & 0.09 & 0.08 & 0.07 & 0.153 \\
\hline \multicolumn{7}{|l|}{ Fertilizer levels } \\
\hline $\mathrm{F}_{0}:$ Control & 4.85 & 4.83 & 3.14 & 8.17 & 8.11 & 7.99 \\
\hline $\begin{array}{l}\mathrm{F}_{1}: 25 \% \text { RDF below seed } \\
\text { placement }\end{array}$ & 5.40 & 6.15 & 5.26 & 8.26 & 8.23 & 8.13 \\
\hline $\begin{array}{l}\mathrm{F}_{2}: 50 \% \text { RDF below seed } \\
\text { placement }\end{array}$ & 6.03 & 6.30 & 6.52 & 8.38 & 8.28 & 8.10 \\
\hline $\begin{array}{l}\mathrm{F}_{3}: 75 \% \text { RDF below seed } \\
\text { placement }\end{array}$ & 6.51 & 6.63 & 7.19 & 8.52 & 8.30 & 8.24 \\
\hline $\begin{array}{l}\mathrm{F}_{4}: 100 \% \text { RDF below seed } \\
\text { placement }\end{array}$ & 7.22 & 6.94 & 8.10 & 8.72 & 8.44 & 8.29 \\
\hline $\begin{array}{l}\mathrm{F}_{5}: 100 \% \text { RDF through } \\
\text { line application }\end{array}$ & 6.71 & 6.57 & 7.51 & 8.45 & 8.40 & 8.26 \\
\hline F. test & Sig. & Sig. & Sig & Sig. & Sig. & Sig \\
\hline S.Em. \pm & 0.15 & 0.08 & 0.08 & 0.03 & 0.03 & 0.049 \\
\hline C.D. at $5 \%$ & 0.43 & 0.22 & 0.24 & 0.10 & 0.08 & 0.142 \\
\hline General mean & 6.12 & 6.24 & 6.29 & 8.42 & 8.29 & 8.17 \\
\hline
\end{tabular}


Table.4 Grain and stover yield of cowpea as influenced by different treatments during year 2011-12, 2012-13, 2013-14 and pooled

\begin{tabular}{|c|c|c|c|c|c|c|c|c|}
\hline \multirow[t]{2}{*}{ Treatments } & \multicolumn{4}{|c|}{ Grain yield (t/ha.) } & \multicolumn{4}{|c|}{ Stover yield (t/ha.) } \\
\hline & $\begin{array}{c}2011- \\
12\end{array}$ & $\begin{array}{c}2012- \\
13\end{array}$ & $\begin{array}{c}2013- \\
14\end{array}$ & Pooled & $\begin{array}{c}2011- \\
12\end{array}$ & $\begin{array}{c}2012- \\
13\end{array}$ & $\begin{array}{c}2013- \\
14\end{array}$ & Pooled \\
\hline \multicolumn{9}{|l|}{ Irrigation levels } \\
\hline $\mathrm{I}_{0}:$ Control & 0.742 & 0.749 & 0.759 & 0.75 & 1.64 & 1.47 & 1.40 & 1.50 \\
\hline $\mathrm{I}_{1}$ : One irrigation (At Br.) & 1.000 & 0.900 & 0.799 & 0.88 & 2.12 & 1.66 & 1.55 & 1.77 \\
\hline $\begin{array}{l}\mathrm{I}_{2}: \text { Two irrigation (At Br. and } \\
\text { P.F.) }\end{array}$ & 1.226 & 1.058 & 0.931 & 1.05 & 2.61 & 1.82 & 1.68 & 2.04 \\
\hline F. test & Sig. & Sig. & Sig. & Sig. & Sig. & Sig. & Sig. & Sig. \\
\hline S.Em. \pm & 0.037 & 0.009 & 0.017 & 0.009 & 0.065 & 0.020 & 0.013 & 0.023 \\
\hline C.D. at $5 \%$ & 0.135 & 0.035 & 0.068 & 0.028 & 0.226 & 0.079 & 0.053 & 0.071 \\
\hline \multicolumn{9}{|l|}{ Fertilizer levels } \\
\hline $\mathrm{F}_{0}$ : Control & 0.667 & 0.709 & 0.578 & 0.694 & 1.52 & 1.30 & 1.24 & 1.35 \\
\hline $\begin{array}{l}\mathrm{F}_{1}: 25 \% \mathrm{RDF} \text { below seed } \\
\text { placement }\end{array}$ & 0.809 & 0.824 & 0.732 & 0.809 & 1.75 & 1.47 & 1.38 & 1.53 \\
\hline $\begin{array}{l}\mathrm{F}_{2}: 50 \% \mathrm{RDF} \text { below seed } \\
\text { placement }\end{array}$ & 0.970 & 0.907 & 0.803 & 0.886 & 2.04 & 1.63 & 1.51 & 1.73 \\
\hline $\begin{array}{l}\mathrm{F}_{3}: 75 \% \mathrm{RDF} \text { below seed } \\
\text { placement }\end{array}$ & 0.109 & 0.943 & 0.911 & 0.945 & 2.27 & 1.77 & 1.61 & 1.88 \\
\hline $\begin{array}{l}\mathrm{F}_{4}: 100 \% \text { RDF below seed } \\
\text { placement }\end{array}$ & 0.122 & 0.102 & 0.976 & 1.058 & 2.65 & 1.92 & 1.79 & 2.12 \\
\hline $\begin{array}{l}\mathrm{F}_{5}: 100 \% \mathrm{RDF} \text { through line } \\
\text { application }\end{array}$ & 0.113 & 0.100 & 0.943 & 1.001 & 2.51 & 1.81 & 1.71 & 2.01 \\
\hline F. test & Sig. & Sig. & Sig. & sig & Sig. & Sig. & Sig. & Sig. \\
\hline S.Em. \pm & 0.04 & 0.020 & 0.016 & 0.017 & 0.75 & 0.26 & 0.15 & 0.027 \\
\hline C.D. at $5 \%$ & 0.12 & 0.057 & 0.048 & 0.048 & 2.17 & 0.76 & 0.45 & 0.076 \\
\hline General mean & 0.989 & 0.902 & 0.830 & 0.898 & 2.12 & 1.65 & 1.54 & 1.77 \\
\hline
\end{tabular}


Table.5 Total cost, gross income, net income and B: C ratio of cowpea as influenced by different treatment combinations

\begin{tabular}{|c|c|c|c|c|}
\hline $\begin{array}{c}\text { Treatments } \\
\text { Combinations }\end{array}$ & $\begin{array}{l}\text { Total cost (Rs. } \\
\left.\text { ha }^{-1}\right)\end{array}$ & $\begin{array}{l}\text { Gross income } \\
\left(\text { Rs. ha }{ }^{-1}\right)\end{array}$ & $\begin{array}{l}\text { Net income } \\
\left(\text { Rs. ha }{ }^{-1}\right)\end{array}$ & $\mathrm{B}: \mathrm{C}$ ratio \\
\hline $\mathbf{I}_{0} \mathbf{F}_{0}$ & 31869 & 36934 & 5064 & 1.16 \\
\hline $\mathbf{I}_{0} \mathbf{F}_{1}$ & 34863 & 43810 & 8947 & 1.26 \\
\hline $\mathbf{I}_{0} \mathbf{F}_{2}$ & 37772 & 50152 & 12380 & 1.33 \\
\hline $\mathbf{I}_{0} \mathbf{F}_{3}$ & 40370 & 54630 & 14259 & 1.35 \\
\hline $\mathbf{I}_{0} \mathbf{F}_{4}$ & 43026 & 59452 & 16426 & 1.38 \\
\hline $\mathbf{I}_{0} \mathbf{F}_{5}$ & 42556 & 55628 & 13072 & 1.31 \\
\hline $\mathbf{I}_{1} \mathbf{F}_{0}$ & 33517 & 39303 & 5786 & 1.17 \\
\hline $\mathbf{I}_{1} \mathbf{F}_{1}$ & 36723 & 47429 & 10705 & 1.29 \\
\hline $\mathbf{I}_{1} \mathbf{F}_{2}$ & 39581 & 53458 & 13877 & 1.35 \\
\hline $\mathbf{I}_{1} \mathbf{F}_{3}$ & 42119 & 56638 & 14520 & 1.34 \\
\hline $\mathbf{I}_{1} \mathbf{F}_{4}$ & 44765 & 61977 & 17212 & 1.38 \\
\hline $\mathbf{I}_{1} \mathbf{F}_{5}$ & 44377 & 60007 & 15631 & 1.35 \\
\hline $\mathbf{I}_{2} \mathbf{F}_{0}$ & 35294 & 41222 & 5928 & 1.17 \\
\hline $\mathbf{I}_{2} \mathbf{F}_{1}$ & 39211 & 54805 & 15595 & 1.39 \\
\hline $\mathbf{I}_{2} \mathbf{F}_{2}$ & 42315 & 62319 & 20004 & 1.47 \\
\hline $\mathbf{I}_{2} \mathbf{F}_{3}$ & 45067 & 67721 & 22654 & 1.50 \\
\hline $\mathrm{I}_{2} \mathrm{~F}_{4}$ & 47697 & 72385 & 24687 & 1.51 \\
\hline $\mathbf{I}_{2} \mathbf{F}_{5}$ & 47376 & 70455 & 23079 & 1.49 \\
\hline
\end{tabular}

These findings were in conformity with those reported by Singh et al., (2006) and Gami and Thanki (2011).

\section{Grain yield}

Irrigations applied at branching and pod filling stage to rabi cowpea significantly increased the grain yield and straw yield over control. The irrigation treatment $\mathrm{I}_{2}$ recorded significantly higher grain and straw yield (t/ha) (Two irrigation at branching and pod filling stage) recorded significantly higher grain yield and stover yield during year 2011$12,2012-13$ and 2013-14 than treatments $I_{1}$ and $\mathrm{I}_{0}$. Treatment $\mathrm{F}_{4}(100 \%$ R.D.F. below seed placement) recorded significantly higher grain yield and stover yield over rest of the treatment except treatment $\mathrm{F}_{5}$ for stover yield which remained statistically at par with each other but significantly superior over rest of the treatments during year 2011-12, 2012-13 and 2013-14 (Table 4).

Pooled data of grain yield and straw yield of year 2011-12, 2012-13, 2013-14. Treatment $I_{2}$ 
(Two irrigation at branching and pod filling stage) recorded significantly higher grain yield and stover yield followed by treatment $\mathrm{I}_{1}$ (one irrigation at branching)during all the three years and in pooled mean. Treatment $\mathrm{F}_{4}$ (100 \% R.D.F. below seed placement) recorded significantly higher grain yield over rest of the treatment except treatment $\mathrm{F}_{5}(100 \% \mathrm{RDF}$ through line application) which remained statistically at par with each other but found significantly superior over rest of the treatments during all the three years and in pooled mean.

Treatment $\mathrm{F}_{4}$ (100 \% R.D.F. below seed placement) recorded significantly higher stover yield over rest of the treatment except treatment $\mathrm{F}_{5}$ which remained statistically at par with each other but significantly superior over rest of the treatments during year 201112 but treatment $\mathrm{F}_{4}$ was significantly superior over rest of the treatments during year 201213, 2013-14 and pooled mean.

The increase in grain and straw yield in treatment $I_{2}$ was mainly attributed due to higher moisture availability due to two irrigations at the critical growth stages (branching and pod filling) of cowpea. Increase in grain and straw yield due to cumulative effect of better growth attributes resulted in better partitioning of photosynthesis in yield attributes and finally produced maximum yield contributing parameters in terms of grain. The better plant growth and improved yield attributes finally led to higher grain and stover yield, results are in line with Babar and Dongale (2011). Nitrogen being a highly mobile nutrient is subjected to greater leaching losses highly permeable light textural soil in the form of nitrates besides being subjected volatilization and denitrification losses, placement showed its superior to line application of fertilizer. Therefore, increase in grain yield in treatment $\mathrm{F}_{4}$ was mainly attributed due to application of
$100 \%$ RDF below seed placement of fertilizers. The increase in grain yield over control due to treatments $F_{4}, F_{5}, F_{3}, F_{2}$ and $F_{1}$

\section{Economics}

Various irrigation treatments significantly increased the net returns and benefit to cost ratio over control. Among the different irrigation treatments application of irrigation at branching and pod filling stage under zero tilled condition along with 100\% recommended dose of fertilizer gave significantly higher net returns (Rs. 24687 $\mathrm{ha}^{-1}$ ) over the control treatment (Table 5). The highest benefit to cost ratio was recorded under application of two irrigations at branching and pod filling stage along with $100 \%$ recommended dose of fertilizer (1.51) which was significantly superior over control treatment. The increased net returns and benefit to cost ratio were mainly due to increased grain yield and straw yield under application of two irrigations at branching and pod filling stage which was significantly superior over control treatment. These results are in line with the findings of Subhendu et al., (2005), Singh et al., (2006).

On pooled analysis, it can be concluded that under zero tilled condition during rabi season, two irrigations(at branching and pod filling stage) along with $100 \%$ recommended dose of fertilizer (25:50:00 N \& P Kg ha ${ }^{-1}$ ) applied below seed showed significantly higher yield of cowpea grain and net monetary returns.

\section{References}

Ahlawat, I.P.S., Singh, A. and C.S. Saraf (1981). Effect of winter legumes on nitrogen economy and productivity of succeeding cereals. Experimental Agriculture, 17: 57-62.

Bachchhav, S.M., Jadhav, A.S., Naidu, T.R. and V.M.M. Bachchhav (1994). Effects 
of irrigation and nitrogen on leaf area, nodulation and dry matter production in summer green gram. J. Maharashtra agric. Univ., 19(2): 211-213.

Gavit, H. D., Rajemahadik, V. A., Bahure, G. K., Jadhav, M. S., Thorat, T. N., and Kasture, M. C. (2017). Effect of Establishment Techniques and Sowing Time on Yield and Yield Attributes of Proso Millet (Panicum miliaceum L.). Int. J. Curr. Microbiol. App. Sci, 6(5), 1523-1528.

Madane Ananda Jagannath, MG Chavan, VA Rajemahadik, JK Singh (2014)Response of Summer Blackgram (Vigna mungo) Varieties to Phosphorus Levels under Lateritic Soils of KonkanInt. J. Sci. Engr. Pp. 259-262.

Gami. M.R. and J.D. Thanki (2011). Influence of moisture regimes and fertilizer management with and without F.Y.M on summer green gram. Green farming, 2(3): 322-325.

Hossian, M.F., M.R Uddin, M.N Islam, M.G Azam and M.R.H Mondol (2009). Response of irrigation in mungbean cultivation at different growth stages. Intl J. Sustainable Agric. Technol., 5(2):11-13.

Rajemahadik V A, Chavan V G, More V G.(2018) Textbook of Irrigation and Water Management Vol.1 PP-91-96.

Panse, V.G. and Sukhatme, P.V. (1967),
Statistical methods for Agricultural workers, I.C.A.R., New Delhi.

Rana, N.S. and R. Singh (1998) Effect of nitrogen and phosphorus on growth and yield of French bean (Phaseolus vulgaris). Indian J. Agron., 43(2): 367370.

Sawant, C.V., Khanvilkar, S.A., Mahale, S.S., and S.V. Kanade (1992). Irrigation and phosphorus requirement of cowpea in konkan. J. Maharashtra agric. Univ., 17(2): 325-326.

Shersingh, Saini, S.S. and B.P. Singh (2004). Effect of irrigation, sulphur and seed inoculation on growth, yield and sulphur uptake of chickpea under late sown condition. Indian J. Agron., 49(1): 57-59.

Singh, A.K., Tripathi, P.N., Kumar, R.P., Shrivastav, A.K. and Room Singh (2006). Response of nitrogen, phosphorus levels and rhizobium inoculation on nutrient uptake, yield and protein content of cowpea. J. Soils and Crops, 16(2): 475-477.

Subhendu Mandal, K.C Biswal and P.K Jana. (2005). Yield, economics, nutrient uptake and consumptive use of water by summer greengram (Vigna radiate L.) as influenced by irrigation and phosphorus application. Legume Research, 28(2): 131-133.

\section{How to cite this article:}

Rajemahadik, V.A., V.N. Shetye, V.G. Chavan, S.A. Chavan and Mahadkar, U.V. 2018. Irrigation and Fertilizer Management in Cowpea under Zero Tilled Condition of South Konkan Coastal Zone of Maharashtra, India. Int.J.Curr.Microbiol.App.Sci. 7(12): 2713-2724. doi: https://doi.org/10.20546/ijcmas.2018.712.309 